\title{
Kajian Karakteristik Proses Pengomposan Limbah Tanaman Jagung yang Diberi Tambahan Kipahit dan Pupuk Kandang Sapi
}

\section{Characteristic Study of Corn Waste Composting Process with Tithonia and Cattle Manure Addition}

\author{
Sophia Dwiratna ${ }^{1}$, Edy Suryadi ${ }^{1}$, Dwi Rustam Kendarto ${ }^{1}$, Kharistya Amaru ${ }^{1}$, Wahyu \\ Kristian Sugandi ${ }^{1}$, Nur Ilham Tri Hartono ${ }^{2}$ \\ ${ }^{1}$ Departemen Teknik Pertanian dan Biosistem, Fakultas Teknologi Industri Pertanian, Universitas Padjadjaran \\ ${ }^{2}$ Program Studi Teknik Pertanian, Fakultas Teknologi Industri Pertanian, Universitas Padjadjaran \\ 『omunikasi Penulis, email: sophia.dwiratna@unpad.ac.id \\ DOI:http://dx.doi.org/10.23960/jtep-lv10i4.432-439
}

Naskah ini diterima pada 30 Agustus 2021; revisi pada 1 Desember 2021; disetujui untuk dipublikasikan pada 20 Desember 2021

\begin{abstract}
Corn waste, tithonia and cattle manure are three materials that have different characteristics. These charactersitics differences if used together in the composting process will complement each other and potentially produce good compost. This research was conducted to find out how the composting process characteristics by utilizing the three raw materials with different characteristics in a composting process. The composting process was carried out using a Berkeley method which was stacked with a layered bioreactor. The decomposition process that occurs involving decompisted bacteria, so the composting process runs aerobically. Aerobic composting corn waste with the addition of tithonia and cattle manure finished in about 4-5 weeks to become a mature compost. The quality of the compost produced is quite good because the content contained in compost fulfills most of the quality standards regulated in SNI 7763: 2018. The addition of tithonia and cattle manure has a positive impact in the process of composting corn plants in terms of duration and good compost.
\end{abstract}

Key words : aerobic, cattle manure, composting, corn waste, tithonia

\begin{abstract}
ABSTRAK
Limbah tanaman jagung, tanaman kipahit dan pupuk kandang sapi merupakan tiga bahan yang memiliki karakteristik yang berbeda-beda. Perbedaan karakteristik tersebut jika dimanfaatkan secara bersama-sama dalam proses pengomposan akan saling melengkapi dan berpotensi menghasilkan kompos yang baik. Penelitian ini dilakukan untuk mengetahui bagaimana karakteristik proses pengomposan dengan memanfaatkan ketiga bahan baku dengan karakteristik yang berbeda-beda dalam suatu proses pengomposan. Proses pengomposan dilakukan menggunakan metode Berkeley yang ditumpuk secara berlapis pada suatu bioreaktor. Proses dekomposisi yang terjadi melibatkan bakteri pengurai, sehingga proses pengomposan berjalan secara aerobik. Pengomposan secara aerobik limbah tanaman jagung dengan penambahan tanaman kipahit dan pupuk kandang sapi selesai dalam waktu sekitar 4-5 minggu untuk menjadi kompos yang matang. Kualitas kompos yang dihasilkan cukup baik karena kandungan yang terdapat di dalam kompos memenuhi sebagian besar dari baku mutu yang diatur di dalam SNI 7763:2018. Penambahan tanaman kipahit dan pupuk kandang sapi memberikan dampak positif dalam proses pengomposan limbah tanaman jagung dari segi durasi dan hasil kompos yang cukup baik.
\end{abstract}

Kata kunci: aerobik, kipahit, limbah tanaman jagung, pengomposan, pupuk kandang sapi

\section{PENDAHULUAN}

Pertanian merupakan salah satu sektor yang memiliki peranan penting dalam hal pertumbuhan ekonomi. Komoditas tanaman jagung merupakan salah satu tanaman pangan terbesar kedua setelah tanaman padi yang memiliki pengaruh pada pertumbuhan ekonomi dengan kontribusi terhadap PDB sekitar 15,67\% dan diproyeksikan meningkar $1,2 \%$ setiap 
tahunnya (Sulaiman et al, 2017). Hal ini menunjukkan bahwa tanaman jagung merupakan salah satu tanaman komoditas pangan yang sangat diminati oleh masyarakat Indonesia selain padi sebagai penghasil beras. Produksi jagung di Indonesia mengalami perkembangan 5,44\% setiap tahunnya (Pusdatin Kementan, 2016). Peningkatan produksi jagung yang terjadi mengakibatkan peningkatan jumlah limbah jagung yang perlu ditangani. Limbah jagung yang dihasilkan dari proses produksi jagung dapat menjadi bahan baku utama pembuatan kompos. Limbah jagung yang dimanfaatkan menjadi kompos adalah suatu upaya mengembalikan bahan organik ke dalam tanah yang dimana akan berdampak baik pada kesuburan tanah dan produksi tanaman serta akan diperoleh manfaat dengan jangka panjang dalam menjaga kesuburan dan kelestarian tanah (Haitami et al, 2019). Limbah tanaman jagung memiliki kandungan selulosa yang tinggi sehingga nilai rasio $\mathrm{C} / \mathrm{N}$ limbah tanaman jagung yaitu 59 (Shah, 2014). Tingginya nilai rasio C/N pada limbah tanaman jagung membuat limbah tersebut sulit terdekomposisi sehingga perlu diturunkan nilai rasio $\mathrm{C} / \mathrm{N}$ nya. Penurunan nilai $\mathrm{C} / \mathrm{N}$ rasio memiliki manfaat efisiensi waktu dalam proses pengomposan (Ekawandani, 2019). Penurunan nilai rasio $\mathrm{C} / \mathrm{N}$ dapat dilakukan dengan menambahkan bahan organik yang mengandung banyak unsur nitrogennya, salah satunya yaitu tanaman kipahit.

Tanaman kipahit (Tithonia diversifolia) atau tanaman bunga matahari Meksiko merupakan tanaman yang tumbuh subur secara liar di wilayah dengan iklim basah serta memiliki nilai rasio $\mathrm{C} / \mathrm{N}$ yang rendah yaitu sekitar 21,2 dan mengandung nitrogen sebesar $0,9 \%$ (Hija, 2021). Nilai rasio $\mathrm{C} / \mathrm{N}$ yang rendah dari tanaman kipahit dapat menjadi sumber nitrogen di dalam campuran bahan baku proses pengomposan yang dimana tanaman kipahit sendiri belum dimanfaatkan secara optimal. Sumber nitrogen pada kipahit dapat digunakan oleh mikroorganisme yang mengurai bahan organik pada proses pengomposan dan mikroorganisme tersebut dapat diperoleh dari pupuk kandang sapi. Penambahan pupuk kandang sapi pada campuran kompos dapat menjadi sumber mikroorganisme pada proses pengomposan serta mengandung unsur N, P dan K (Riyani et al, 2015). Penggunaan tanaman kipahit dan pupuk kandang dalam proses pengomposan memberikan dampak yang baik dalam proses pengomposan, kompos yang dihasilkan memenuhi standar mutu SNI 7763:2018 serta memberikan dampak yang baik terhadap proses pengomposan limbah jagung (Dwiratna, 2021).

Ketiga bahan tersebut memiliki karakteristik yang berbeda-beda, namun memiliki potensi untuk dapat saling melengkapi di dalam suatu proses yaitu pengomposan. Penelitian mengenai pemannfaatan limbah tanaman jagung, tanaman kipahit dan pupuk kandang sapi secara bersamaan dalam proses pengomposan belum pernah dilakukan, sehingga menarik dilakukan penelitian untuk mengetahui karakteristik proses pengomposan yang terjadi ketika ketiga bahan dimanfaatkan secara bersama. Tujuan penelitian ini dilakukan adalah untuk mengetahui karakteristik proses pengomposan limbah tanaman jagung yang ditambahkan kipahit dan pupuk kandang sapi dan membandingkan hasil kompos dengan standar SNI 7763:2018.

\section{BAHAN DAN METODE}

Penelitian ini dilaksanakan di Ciparanje, Universitas Padjadjaran pada bulan Januari Agustus 2021. Alat yang digunakan dalam penelitian adalah bioreaktor, termometer tanah, soil moisture tester dan meteran. Bahan yang digunakan dalam penelitian adalah cacahan limbah tanaman jagung, cacahan tanaman kipahit, pupuk kandang sapi dan EM4.

Penelitian dilakukan secara deskriptif dengan menggunakan 3 bioreaktor, masing-masing bioreaktor diisi dengan ketiga bahan baku dengan imbangan yang berbeda-beda. Perhitungan imbangan bahan dilakukan secara teoritis sehingga menghasilkan kondisi $\mathrm{CN}$ rasio 30:1 untuk bioreaktor 1, 35:1 untuk bioreaktor 2 dan 40:1 untuk bioreaktor 3 .

\subsection{Perhitungan Imbangan Bahan Baku}

Kandungan hara masing-masing bahan baku yang digunakan dilakukan analisis di laboratorium dan disajikan pada Tabel 1. 
Tabel 1. Kandungan Hara Bahan Baku Kompos

\begin{tabular}{clccc}
\hline No & Nama Bahan & Mositure (\%) & C (\%) & N (\%) \\
\hline 1 & Jagung & 34,695 & 30,83 & 0,685 \\
2 & Kipahit & 78,62 & 11,13 & 0,485 \\
3 & Pupuk Kandang Sapi & 54,4 & 8,815 & 0,65 \\
\hline
\end{tabular}

Tabel 2. Imbangan Bahan Baku Kompos

\begin{tabular}{cccc}
\hline Nilai Rasio C/N & Jagung (kg) & Kipahit (kg) & $\begin{array}{c}\text { Pupuk Kandang } \\
\text { Sapi (Kg) }\end{array}$ \\
\hline 30 & 80 & 60 & 60 \\
35 & 105 & 50 & 45 \\
40 & 130 & 145 & 140 \\
\hline
\end{tabular}

Data bahan baku yang telah diperoleh dimasukan ke dalam persamaan nilai rasio $\mathrm{C} / \mathrm{N}$ sebagai berikut (Rynk, 1992):

$$
\mathrm{C} / \mathrm{N}=\frac{[\mathrm{Ca} \times \mathrm{Qax}(100-\mathrm{Ma})]+[\mathrm{Cb} \times \mathrm{Qb} \times(100-\mathrm{Mb})]+[\mathrm{Cc} \times \mathrm{Qc} \times(100-\mathrm{Mc})]}{[\mathrm{Na} \times \mathrm{Qa} \times(100-\mathrm{Ma})]+[\mathrm{Nb} \times \mathrm{Qb} \times(100-\mathrm{Mb})]+[\mathrm{Nc} \times \mathrm{Qc} \times(100-\mathrm{Mc})]}
$$

dimana Qa, Qb, Qc merupakan total massa bahan a, b, c; Ma, Mb, Mc adalah moisture bahan a, b, c; $\mathrm{Ca}, \mathrm{Cb}, \mathrm{Cc}$ adalah \% kandungan karbon bahan a, b, c; dan $\mathrm{Na}, \mathrm{Nb}, \mathrm{Nc}$ adalah \% kandungan nitrogen bahan a, b, c.

Menurut Rynk (1992), pengomposan akan menghasilkan hasil kompos yang baik dianjurkan menggunakan nilai rasio $\mathrm{C} / \mathrm{N}$ awal pada rentang 20-40. Nilai rasio $\mathrm{C} / \mathrm{N}$ awal yang memberikan hasil kompos yang paling baik dari segi sifat fisik maupun kimia adalah 30:1 (Luciawati, 2018). Dengan demikian ditentukan nilai rasio $\mathrm{C} / \mathrm{N}$ sesuai dengan nilai rasio $\mathrm{C} / \mathrm{N}$ yang dikehendaki yaitu 30, 35 dan 40 maka didapatkan imbangan komposisi setiap bahan baku disajikan pada Tabel 2.

\subsection{Proses Pembuatan Kompos}

Bahan baku diambil dari sekitar wilayah penelitian karena disekitar wilayah penelitian terdapat perkebunan jagung, banyak tumbuh secara liar tanaman kipahit serta terdapat kandang sapi yang dapat menghasilkan pupuk kandang sapi. Bahan hijauan seperti limbah tanaman jagung dan tanaman kipahit dicacah menggunakan mesin pencacah hingga ukuran bahan menjadi 4-5 cm. Tujuan pencacahan agar proses pengomposan berjalan cepat karena kecilnya ukuran bahan baku maka akan semakin mudah mikoorganisme untuk menguraikannya (Setyorini et al, 2006).

Bahan baku yang telah dicacah, ditumpuk ke dalam bioreaktor secara berlapis mulai dari cacahan limbah tanaman jagung, diikuti dengan cacahan tanaman kipahit dan pupuk kandang sapi serta setiap lapis disemprotkan dengan larutan EM4. Larutan EM4 yang digunakan adalah campuran dari EM4, air dan gula merah dengan perbandingan masing-masing 50:1:1 menghasilkan 30 liter larutan EM4 yang diberikan pada setiap bioreaktor sebanyak 10 liter.

Bioreaktor yang digunakan sebanyak 3 buah dan dilengkapi dengan pipa aerasi (Gambar 1). Setiap bioreaktor menampung bahan baku kompos dengan imbangan bahan baku yang telah ditentukan sebelumnya. Metode pengomposan yang digunakan adalah metode Berkeley, dimana metode berkeley ini cocok digunakan karena metode ini memadukan antara bahan yang mengandung karbon dengan bahan yang mengandung nitrogen serta pupuk kandang dapat ditambahkan di dalamnya (Setyorini et al, 2006).

Kontrol yang dilakukan selama proses pengomposan berlangsung yaitu penyiraman dengan air ketika tumpukan dianggap kering. Proses pembalikan dilakukan jika suhu tumpukan lebih dari $70^{\circ} \mathrm{C}$, hal ini dilakukan untuk mencegah matinya mikroorganisme pengurai yang akan menyebabkan proses pengomposan tidak berjalan optimal. Lamanya pengamatan yang dilakukan yaitu 50 hari. 


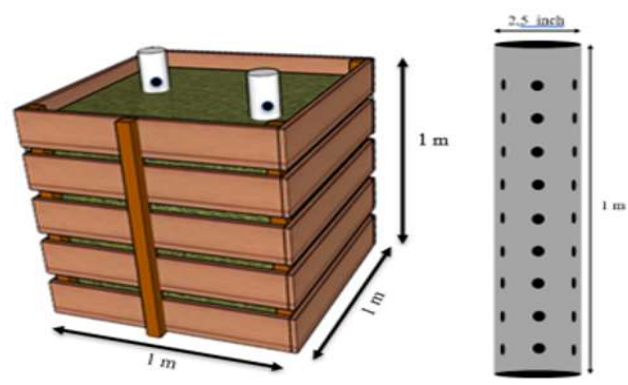

Gambar 1. Desain Bioreaktor dan Pipa Aerasi

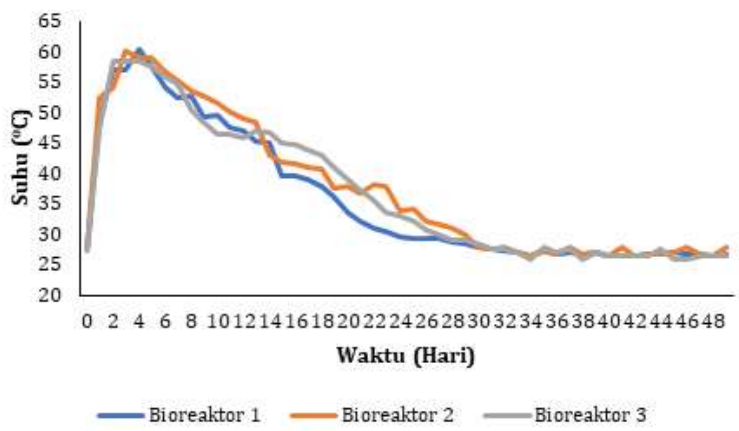

Gambar 2. Dinamika Temperatur Proses Pengomposan Ketiga Bioreaktor

\subsection{Pengamatan}

Pengamatan yang dilakukan selama proses pengomposan antara lain temperatur tumpukan kompos, volume tumpukan kompos, kelembaban tumpukan kompos dan temperatur lingkungan. Pengamatan di akhir penelitian yaitu pengamatan warna, bau dan analisis laboratorium untuk mengetahui kualitas kompos yang dihasilkan. Pengukuran temperatur kompos dilakukan menggunakan termometer tanah dan ditancapkan pada tumpukan kompos tepatnya pada bagian atas, tengah dan bawah untuk mendapatkan suhu keseluruha tumpukan kompos. Pengukuran volume dilakukan dengan menempelkan meteran secara vertikal pada bioreaktor sehingga dapat diketahui penurunan tinggi permukaan kompos setiap harinya, nilai tinggi permukaan kompos dikalikan dengan panjang dan lebar bioreaktor sehingga didapatkan volume kompos.

\section{HASIL DAN PEMBAHASAN}

\subsection{Karakteristik Proses Pengomposan 3.1.1. Dinamika Temperatur Proses Pengomposan}

Dinamika temperatur dalam proses pengomposan memegang peranan penting, hal ini dikarenakan dari dinamika temperatur akan menggambarkan indikator dari dinamika aktivitas yang dilakukan oleh mikroorganisme dalam proses dekomposisi bahan organik. Suatu proses pengomposan mulai memasuki tahap pematangan ditandai dengan suhu kompos menurun dan stabil (Setyorini et al, 2006). Dinamika temperatur pada proses pengomposan disajikan pada Gambar 2.

Dinamika temperatur yang disajikan, menggambarkan proses pengomposan pada ketiga bioreaktor berjalan secara baik dan normal selayaknya proses pengomposan secara aerobik. Ketiga bioreaktor mengalami fase mesofilik relatif bersamaan pada hari ke-1 hingga hari ke-2. Fase mesofilik terjadi pada rentang suhu $32^{\circ} \mathrm{C}$ hingga $43^{\circ} \mathrm{C}$ dimana pada fase ini terjadi perombakan protein dan senyawa gula yang ada pada tumpukan oleh mikroorganisme yang hidup pada fase tersebut (Baldwin dan Greenfield, 2009). Perbedaan mulai muncul ketika memasuki fase termofilik, bioreaktor 1 mengalami puncak suhu tertinggi pada hari ke6, bioreaktor 2 pada hari ke-5 dan bioreaktor 3 pada hari ke-3. Fase termofilik pada proses pengomposan dicirikan dengan suhu tumpukan mencapai sekitar $60^{\circ} \mathrm{C}$, dimana suhu tersebut akan membunuh patogen, larva dan benih gulma (Graves et al, 2000). Kenaikan suhu tersebut menandakan aktivitas mikroorganisme yang 
tinggi dalam menguraikan bahan organik dan juga menandakan bahwa kondisi yang diperlukan dalam proses pengomposan seperti rasio $\mathrm{CN}$, aerasi dan kadar air dapat dipenuhi dan membuat aktivitas mikroorganisme berjalan dengan baik dan proses pengomposan juga berjalan dengan baik.

Bioreaktor 1 mengalami penurunan suhu yang lebih cepat dibandingkan bioreaktor 2 dan bioreaktor 3. Bioreaktor 1 mulai memasuki fase pendinginan pada hari ke-16, bioreaktor 2 pada hari ke-19 dan bioreaktor 3 pada hari ke-21. Fase pendinginan ditandai dengan suhu tumpukan kompos $40^{\circ} \mathrm{C}$ (Graves et al, 2000). Perbedaan waktu ini dikarenakan perbedaan imbangan bahan baku pada setiap bioreaktor. Bioreaktor 1 mengandung lebih sedikit imbangan tanaman jagung dibandingkan dengan bioreaktor lainnya, namun memiliki imbangan tanaman kipahit dan pupuk kandang sapi yang lebih banyak, sehingga sumber bahan organik yang diuraikan lebih sedikit dan diuraikan oleh mikroorganisme yang lebih banyak. Proses dekomposisi pada bioreaktor 1 berjalan lebih cepat dibandingkan dengan bioreaktor 2 dan bioreaktor 3. Fase pendinginan kompos ditandai juga dengan tumbuhnya jamur pada tumpukan kompos yang dapat terlihat pada Gambar 3.
Penurunan suhu tumpukan kompos menandai penurunan aktivitas mikroorganisme dalam mengurai bahan organik. Suhu tumpukan kompos semakin menurun hingga memasuki tahap stabilization. Fase stabilization ditandai dengan suhu kompos mengalami penurunan dan aktivitas mikroorganisme juga menurun (Cooperband, 2002). Menurut Setyorini et al tahun 2006, kompos yang matang ditandai dengan temperatur kompos stabil dan tidak lagi mengalami kenaikan dan penurunan suhu yang siginifikan. Bioreaktor 1 memasuki fase stabilization pada hari ke-25, bioreaktor 2 pada hari ke-31 dan bioreaktor 3 pada hari ke-29 (Setyorini et al, 2006).

\subsection{Reduksi Volume}

Proses pengomposan terjadi penguraian bahan organik oleh mikroorganisme. Proses penguraian akan mengakibatkan terjadinya reduksi volume karena unsur karbon pada tumpukan kompos diurai dan berubah menjadi $\mathrm{CO}_{2}$. Proses penguraian juga menjadikan ukuran partikel semakin kecil dan semakin mampat. Reduksi volume pada proses pengomposan yang berjalan baik bisa terjadi hingga 60\% (CCME, 1996). Reduksi volume yang terjadi selama proses pengomposan disajikan pada Gambar 4 .

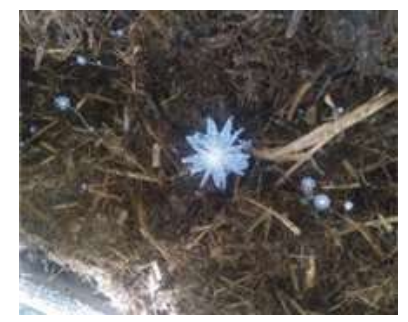

Gambar 3. Jamur pada Tumpukan Kompos

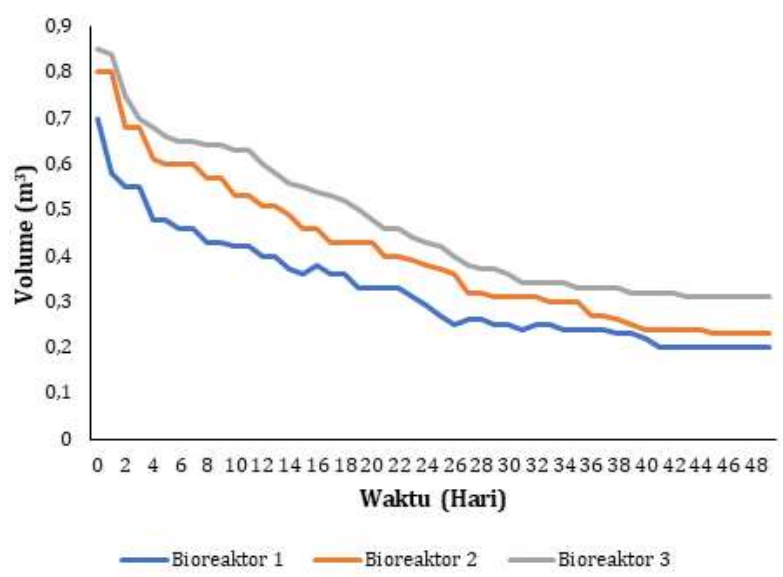

Gambar 4. Volume Tumpukan Kompos Selama Proses Pengomposan 
Berdasarkan Gambar 4, pada minggu ke-1 terjadi reduksi volume yang cukup signifikan sebesar $34 \%$ pada bioreaktor $1,25 \%$ pada bioreaktor 2 dan $23 \%$ pada bioreaktor 3 . Perbedaan besarnya reduksi volume masing-masing bioreaktor diakibatkan oleh perbedaan imbangan bahan baku setiap bioreaktornya. Bioreaktor 1 mengandung lebih banyak pupuk kandang sapi sehingga mikroorganisme pengurai bahan organik di dalam tumpukan lebih banyak dibandingkan bioreactor lainnya.

Reduksi volume yang terjadi secara keseluruhan proses pengomposan untuk bioreaktor 1 terjadi sebesar 71,42\%, bioreaktor 2 sebesar 71,25\% dan bioreaktor 3 sebesar $63,52 \%$. Besarnya reduksi volume dari ketiga bioreaktor sudah masuk kriteria kompos yang matang dengan proses pengomposan yang berjalan baik karena mengalami reduksi volume lebih dari $60 \%$ selama proses pengomosan berlangsung (CCME, 1996).

\subsection{Warna dan Bau Kompos}

Proses pengomposan berlangsung mengakibatkan berubahnya warna tumpukan menjadi kehitaman dan tidak berbau (Setyorini et al, 2006). Bau tumpukan kompos yang dihasilkan dari proses pengomposan pada hari ke-30 sudah tidak berbau, karena proses pengomposan sudah memasuki fase stabilization. Warna yang dihasilkan pada akhir pengomposan disajikan pada Gambar 5.

Ketiga bioreaktor sama-sama menghasilkan kompos yang berwarna kehitaman dan warna kehitaman tersebut menjadi ciri kompos tersebut sudah matang. Pengukuran warna dilakukan dengan menganalisis nilai RGB dan dihasilkan nama warna sesuai dengan nilai RGB menggunakan aplikasi Colormeter. Hasil analisis warna disajikan pada Tabel 3.

\subsection{Analisis Laboratorium}

Pengujian di laboratorium dilakukan untuk mengetahui kualitas kompos yang dihasilkan. Hasil analisis kimia yang dilakukan terhadap ketiga kompos secara umum sudah menjadi kompos yang matang. Rincian hasil analisis laboratorium disajikan pada Tabel 4.

Berdasarkan hasil analisis laboratorium, secara garis besar kompos yang dihasilkan sudah

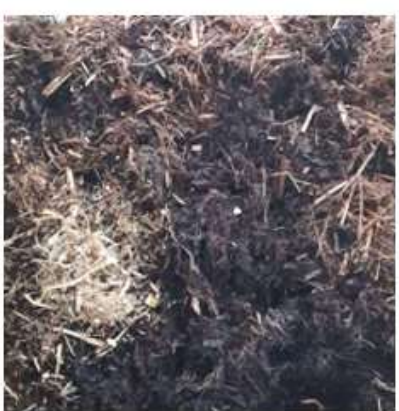

(a)

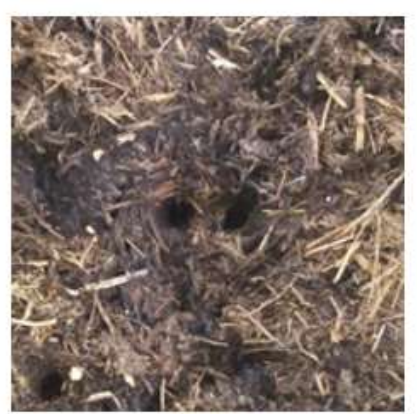

(b)

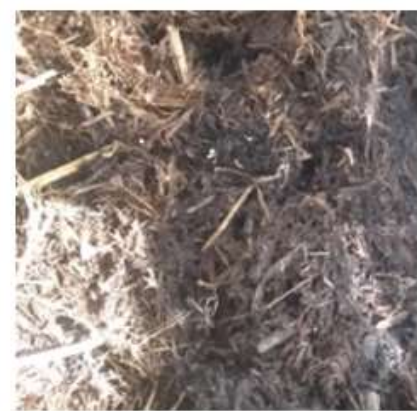

(c)

Gambar 5. Warna Kompos (a) Bioreaktor 1; (b) Bioreaktor 2, dan (c) Bioreaktor 3

Tabel 3. Hasil Analisis Warna Kompos

\begin{tabular}{clll}
\hline Hari ke & Bioreaktor 1 & \multicolumn{1}{c}{ Bioreaktor 2 } & \multicolumn{1}{c}{ Bioreaktor 3 } \\
\hline 1 & Pastel Brown & Pastel Brown & Pastel Brown \\
8 & Pastel Brown & Pastel Brown & Pastel Brown \\
15 & Pastel Brown & Pastel Brown & Pastel Brown \\
22 & Dark Lava & Dark Lava & Pastel Brown \\
29 & Dark Lava & Dark Lava & Dark Lava \\
36 & Bistre & Dark Lava & Dark Lava \\
43 & Bistre & Bistre & Dark Lava \\
50 & Bistre & Bistre & Bistre \\
\hline
\end{tabular}


Tabel 4. Hasil Analisis Laborratorium Hasil Kompos

\begin{tabular}{clcllll}
\hline No & \multirow{2}{*}{ Parameter } & Satuan & $\begin{array}{c}\text { Bioreaktor } \\
\mathbf{1}\end{array}$ & $\begin{array}{c}\text { Bioreaktor } \\
\mathbf{2}\end{array}$ & $\begin{array}{c}\text { Bioreaktor } \\
\mathbf{3}\end{array}$ & \multicolumn{1}{c}{ SNI } \\
\hline 1 & Kadar Air & $\%$ & 62,49 & 58,86 & 68,18 & $8-25$ \\
2 & $\mathrm{pH}$ & & $9,25\left(\mathrm{H}_{2} \mathrm{O}\right)$ & $9,3\left(\mathrm{H}_{2} \mathrm{O}\right)$ & $9\left(\mathrm{H}_{2} \mathrm{O}\right)$ & \\
& & & $8,6(\mathrm{KCl})$ & $8,6(\mathrm{KCl})$ & $8,55(\mathrm{KCl})$ & $4-9$ \\
3 & $\mathrm{CN}$ & & 12 & 14 & 15,5 & Maks. 25 \\
4 & $\mathrm{C} \mathrm{Organik}$ & & 9,86 & 10,99 & 11,9 & Min. 15 \\
5 & $\mathrm{~N}+\mathrm{P}_{2} \mathrm{O}_{5}+\mathrm{K}_{2} \mathrm{O}$ & $\%$ & 2,57 & 2,56 & 2,55 & Min. 2 \\
6 & $\mathrm{Mg}$ & $\%$ & 0,4 & 0,36 & 0,27 & Maks $0,6^{* *}$ \\
7 & $\mathrm{Fe}$ & $\mathrm{ppm}$ & 8411 & 6731 & 3774 & Maks $9000^{*}$ \\
8 & $\mathrm{Zn}$ & $\mathrm{ppm}$ & 37 & 40 & 23 & Maks $5000^{*}$ \\
\hline
\end{tabular}

Keterangan :*) Permentan No.70 Tahun 2011, ${ }^{* *}$ ) SNI 19-7030-2004

dikategorikan kompos yang matang dan kualitas dari kompos cukup baik. Kandungan hara makro dan mikro pada kompos secara mayoritas sudah memenuhi SNI 7763:2018. Namun, untuk beberapa parameter seperti kandungan air dan C organik masih belum memenuhi SNI 7763:2018. Kandungan C organik yang masih belum memenuhi standar dapat diatasi dengan mengatur imbangan kompos dengan memperbanyak bahan tanaman jagung, karena nilai $\mathrm{C}$ organik dipengaruhi oleh banyaknya jerami jagung pada tumpukan kompos. Hal ini dikuatkan dengan nilai $C$ organik pada bioreaktor 3 lebih tinggi dibandingkan bioreaktor 1 dan 2 yang dimana pada bioreaktor 3 mengandung bahan limbah tanaman jagung lebih banyak. Kadar air yang tinggi dan tidak memenuhi SNI 7763:2018 dapat diatasi dengan pembalikan tumpukan kompos secara berkala agar kandungan air dapat terjaga. Nilai $\mathrm{pH}$ produk kompos termasuk alkali diakibatkan kadar air pada kompos tinggi, sehingga perlu penambahan bahan yang dapat menurunkan nilai $\mathrm{pH}$ pada kompos.

\section{KESIMPULAN DAN SARAN}

\subsection{Kesimpulan}

Karakteristik proses pengomposan limbah tanaman jagung yang diberi tambahan kipahit dan pupuk kandang sapi adalah membutuhkan waktu yang lebih cepat untuk menghasilkan kompos yang matang sekitar 4-5 minggu, dibandingkan proses dekomposisi limbah tanaman jagung yang bisa menghabiskan waktu
4-5 bulan. Kualitas kompos yang dihasilkan cukup baik, mayoritas parameter kualitas kompos memenuhi SNI 7763:2018. Penambahan kipahit dan pupuk kandang sapi dalam proses pengomposan limbah tanaman jagung memberikan dampak positif dari segi efisiensi waktu.

\subsection{Saran}

Saran yang dapat diberikan berdasarkan penelitian ini adalah menyediakan lahan untuk penanaman tanaman kipahit di sekitar lahan penanaman tanaman jagung atau tanaman utama lainnya yang memiliki karakteristik serupa denggan tanaman jagung. Hal ini bisa dilakukan untuk mengatasi masalah limbah tanaman jagung dengan karakteristiknya untuk terdekomposisi membutuhkan waktu yang lama.

\section{DAFTAR PUSTAKA}

Baldwin, K.R and J. T. Greenfield. 2009. Composting on organic farms. North Carolina : Cooperative Extension Service

CCME (Canadian Council of the Ministers of the Environment). 1996. Guidelines for compost quality. Minister of Public Works and Government Services Canada, Cat. No. EN108-3/1-106E, pp 11.

Cooperband, L. 2002. The art and science of composting. Madison : University of Wisconsin-Madison 
Dwiratna, S., Suryadi, E., Kendarto, D. R., Amaru, K., Sugandi, W. K., dan Pramesti, A. D. 2021. Kajian karakteristik proses pengomposan limbah tanaman jagung yang diberi tambahan kipahit dan pupuk kandang kambing. Rona Teknik Pertanian, 14 (2): 31-41.

Ekawandani, N., dan Kusuma, A. A. 2019. Pengomposan sampah organik (kubis dan kulit pisang) dengan menggunakan EM4. Jurnal TEDC, 12 (1): 38-43.

Graves E. Robert and Gwendolyn M. Hattemer. 2000. Chapter 2 composting. Washington : United States Department of Agriculture

Haitami, A., dan Wahyudi, W. 2019. Pemanfaatam pupuk kompos jagung manis dalam meningktakan produksi tanaman jagung (Zea mays $L$ ) pada Tanah Ultisol. Jurnal Agronomi Tanaman Tropika (JUATIKA), 1 (1): 42-48

Hija, M. F., Junus, M., dan Kamaliyah, S. N. 2021. pengaruh penambahan Effective Microorganisme 4 (EM4) dan lama pengomposan terhadap kualitas pupuk organik dari feses kambing dan daun Paitan (Thitonia diversifolia). Jurnal Dinamika Penelitian Industri, 32 (1): 8594.

Lucitawati, E., Rezagama, A., dan Samudro, G. 2018. Penentuan variasi rasio $\mathrm{C} / \mathrm{N}$ optimum sampah campuran (dedaunan dan sisa makanan) terhadap kinerja Compost Solid Phase Microbial Fuel Cells (CSMFC). Jurnal Presipitasi: Media Komunikasi dan Pengembangan Teknik Lingkungan, 15 (2): 100-105.

Pusdatin Kementan. 2016. Outlook Komoditas Pertanian Sub Sektor Tanaman Pangan : Jagung. Pusat Data dan Sistem Informasi Pertanian, Kementerian Pertanian, Jakarta.

Rahman, M. M. 2013. Carbon dioxide emission from soil. Agricultural Research, 2(2): 132139.

Riyani, N., T. Islami, dan T. Sumarni. 2015. Pengaruh pupuk kandang dan crotalaria juncea l. pada pertumbuhan dan hasil tanaman kedelai (Gycine max L.). Jurnal Produksi Tanaman, 3 (7): 556-563.

Setyorini, D., Rasti S, Ea Kosman A. 2006. Pupuk Organik dan Pupuk Hayati. Bogor: Balai Besar Penelitian dan Pengembangan Sumberdaya Lahan Pertanian.

Shah, Z., Jani, Y. M., \& Khan, F. 2014. Evaluation of organic wastes for composting. communications in soil science and plant analysis, 45 (3): 309-320.

Sulaiman, A. Kariyasa, I.Hoerudin. Subagyono, K. dan Bahar, F. 2017. Cara Cepat Swasembada Jagung. Bogor: IAARD Press 